\title{
Corporate Governance Features and Efficiency: Evidence from the Saudi Arabian Banks
}

\author{
Adel Bogari ${ }^{1}$ \\ ${ }^{1}$ Assistant Professor, College of Business Administration, Al-Baha University, KSA \\ Correspondence: Adel Bogari, Assistant Professor, College of Business Administration, Al-Baha University, \\ KSA. E-mail: aabogari@bu.edu.sa
}

Received: November 21, 2019

Accepted: December 15, 2019 Online Published: December 20, 2019

doi:10.5539/ijef.v12n1p43

URL: https://doi.org/10.5539/ijef.v12n1p43

\begin{abstract}
The aim of this article is to examine the effect of the Corporate Governance features as measured by the Independence of the board of directors, the board size and the ownership structure (private ownership/State ownership and foreign ownership) on the banking efficiency of Saudi Arabian banks. A data set of the twelve biggest banks for the period 2000 to 2017 is used. As for banking efficiency scores, the methodology is based on the Data Envelopment Analysis (DEA). It allows for Technical Efficiency, Pure Technical Efficiency and Scale Efficiency scores. The results of this study point to the significant role of The Independence (INDEP) variable supported by a positive and significant effect on efficiency in all regressions, indicating a positive relationship with the Technical Efficiency (TE) and the Pure Technical Efficiency (PTE). In the contrary, the independence of the board directors has a negative and significant effect on scale efficiency (SE). According to Board Size variable, results related to this later reveal a negative and a significant effect on technical efficiency (TE), Pure Technical Efficiency (PTE) and Scale Efficiency (SE) in all regressions. Finally, as for the ownership structure variables, results confirm that Private Ownership (OWEN-P) provides positive and significant effects on both the Technical and the Scale Efficiency. This effect seems to be turn to be negative and significant when it is correlated to the Pure Technical Efficiency. State Ownership (OWEN-S) impacts positively and significantly the Technical Efficiency, the Pure Technical Efficiency and Scale Efficiency separately. As for the Foreign Ownership (OWEN-F) variable, except for the Pure Technical Efficiency (PTE), we note a positive and significant effect on the Technical and Scale Efficiency. This study implies better Corporate Governance practices should be supported to improve the overall efficiency and its components. This includes in particular, the Board Size and the Ownership structure variables.
\end{abstract}

Keyswords: corporate governance, efficiency, banks, Saudi Arabia

\section{JEL Classification: G21, G29.}

\section{Introduction}

The main role of the financial institutions is to mediate economic activities and intermediate the execs of funds to those who are in need. For this reason, well-functioning financial entities, banks in particular, are usually considered to be a necessary condition to a country's economic growth. In competition with the stock market, banks are the most important participants in the financial System (Diallo, 2018; Belke et al., 2016; Cevik et al., 2016; Zhang et al., 2016). It is important to study the efficiency of the banks to ensure the positive results on economic growth, saving, investment and the most important macroeconomic indicators. Recently, Diallo (2018) states that the financial sector's development is crucial to economic growth and the efficiency of the banking sector is potentially important to the long-term economic growth of countries. Banking efficiency is related to the costs of inputs, as considered in the financial intermediation approach by the cost charged by by deposits, physical capital and the salaries and benefits of the employees. Banks have to look for the optimal distribution of available resources that would allow for achieving the maximum of its production with controlling for the cost of its inputs (Cvilikas \& Edita, 2016). Hence, an improvement in banking efficiency indicates better allocation of financial resources resulting in an increase in investment that favors growth (Cevik et al., 2016). These outcomes prove the great but overlooked importance of bank efficiency in mitigating the negative effects of financial crises and promoting economic growth.

From few years, the economic researchers start investigating the role of the corporate governance in boosting the 
role played by the financial institutions. It seems that some particular features characterizing the financial institutions have significant impact leading to better performance, efficiency and greater access to financing. However, poor corporate governance can lead to distressful conditions of banks and can increase their inefficiency by affecting the quality of bank assets and causing financial volatility of these institutions (Adams \& Mehran, 2012; Yizhe et al., 2016). For this reason, there is an obligation to implement proper corporate governance rules and practices, as governance and efficiency are supposed to be related.

In this article, our interest goes toward investigating the relationship between banking governance and banking efficiency. We try to answer the question: Does the corporate governance affect the efficiency of banks in Saud Arabia? The Kingdom of Saudi Arabia economy has performed strong fundamentals and has enjoyed macroeconomic stability in the last decade. According to the 2030 Vision, Saudi Arabia has developed efforts to diversify the economy, implement structural reforms, and effective management of the economy has encouraged private sector activities and helped attract foreign investment. The four new mega economic cities underlie the kingdom's intentions and efforts to become an industrial hub for cheap energy and international services. Saudi Arabia has made big progress in term of developing the financial sector, namely the stock market and banks. Some achievements have been reached establishing the monetary union in collaboration with Gulf Cooperation Council. In this vein, there is continuing cooperation with the European Union and international experts in this area. The kingdom has embarked on second-generation reforms financial sectors aimed at boosting private sector performance and capacity.

The aim of this article is to explore the role played by the corporate governance practices in promoting banking efficiency in Saudi Arabian banks. Our concern is toward testing the specific features of Banking Governance, namely the dependence of directors Board, the Board Size and the ownership structure on the Technical efficiency, Pure Technical Efficiency and Scale Efficiency scores.

The rest of the article is organized as follows: Section tow reviews briefly the relevant studies from the literature. Section three presents the models and defines the variables and hypotheses. Section four displays the methodology, the sample and the period. Section five presents the empirical findings. Finally, section six concludes.

\section{Brief Literature Review}

Arouri et al. (2014) examine the effect of ownership structure and board composition on bank performance as measured by Tobin's Q and market to book value in Gulf Co-Operation Council (GCC) countries. The authors use a dataset of 58-listed banks of GCC countries for the period 2010 is used. They prove that the extent of family ownership, foreign ownership and institutional ownership has a significant positive association with bank performance. However, government ownership does not have a significant impact on performance. Other governance variables such as CEO duality and board size appear to have an insignificant impact on performance. The study implies that ownership by corporate governance is more effective for GCC countries. The study also suggests that unlike in western countries, corporate boards may not be an effective corporate governance mechanism in GCC countries. Yizhe et al. (2016) dealing with corporate governace and financial volatility relatiship, conclude that a poor corporate governance system can increase risks by affecting the quality of bank assets and causing financial volatility, and is often associated with lack of efficiency. Ibrahim (2017) reveals that good corporate governance provides proper incentives for boards and management to pursue objectives that are in the interests of banks and shareholders and facilitates effective monitoring, thereby encouraging banks to use resources more efficiently. Mezzi (2018) studies on the one hand, the performance of Islamic banks by measuring their efficiency through data envelopment analysis (DEA) method and, on the other hand, the determinants of this efficiency emphasizing on the impact of the governance structure through the panel estimation of Islamic banks based on the three proxies of cost efficiency, namely, technical efficiency (TES), pure technique (PTE) and scale efficiency (SES). In terms of governance, the results show that the board of directors through its size and independence and the presence of a central Sharia board constitute a robust determinant of the Islamic banks' efficiency. The ownership structure and the size of the Sharia board do no effect banking efficiency. Pillai and Al-Malkawi (2018) tries to integrate conventional corporate governance (CG) mechanisms into the Islamic banking framework in order to examine their impact on Islamic banks (IBs) financial performance (IBFP) within the Gulf Cooperation Council (GCC) context. The results show that five internal CG mechanisms have statistically significant relationship with IBFP, measured by Q-ratio. Insider shareholding is found to be positively associated with IBFP, while institutional and government shareholdings are found to be negatively related to Q-ratio, the results being consistent with the agency theory, strategic alignment theory and property rights theory, respectively. The paper examines the relationship between internal CG mechanisms and financial performance of listed and non-listed full-fledged IBs operating in the GCC 
countries. Titova (2016) join the point of vue of Upadhyay and Sriram (2011) that larger boards have greater resources to perform their management monitoring role. Banks with a larger board size are able to be more adequate for solving more complex problems. This likely explains why banks have, on average, more directors on the board than non-financial firms. Adams and Merhan (2012) examined the relationship between board size and bank efficiency in a sample of 35 large US bank holding companies (BHCs) over the 1959-1999 period. Contrary to evidence, they concluded that banks with larger boards do not under-perform their peers in terms of Tobin's Q and that, as a result, constraints on board size in the banking industry may be counter-productive. Yamori et al. (2017) confirm that having a large number of board members has negative effects on efficiency measures for cooperative banks. In addition, while the authors find no significant effect for stock banks, results show that the presence of outside directors has a significant effect on efficiency measure for cooperative banks.

\section{Models and Hypotheses}

We present in this section the useful data and we detail the dependent and independent variables. Then, we explore the specifications between banking efficiency and Corporate Governance Variables. The dependent variables are the efficiency scores estimated according to the Data Envelopment Analysis method in section 4. The models bellow examine the impact of CGV on banking efficiency. A number of bank-specific and country-specific variables are also included to conduct a robust analysis. The independent variables include Corporate Governance variables and the mainly control variables that affect banking efficiency. Therefore, the models are elaborated to provide a comprehensive view of the Corporate Governance factors that affect efficiency scores. We consider the technical efficiency (TE), pure technical efficiency (PTE) and scale efficiency (SE) and we try to estimate each model according to the previous scores of efficiency.

Model 1:

$$
T E_{i t}=\beta_{0}+\beta_{1} C G V_{i t}+\beta_{2} X_{i t} \varepsilon_{i t}
$$

Model 2:

$$
P T E_{i t}=\alpha_{0}+\alpha_{1} C G V_{i t}+\alpha_{2} X_{i t} \varepsilon_{i t}
$$

Model 3:

$$
S E_{i t}=\mu_{0}+\mu_{1} C G V_{i t}+\mu_{2} X_{i t} \varepsilon_{i t}
$$

We select a range of variables which are carefully selected from the literature. We believe that Corporate Governance components may explore much better the effect of Corporate Governance Variables on efficiency. CGV includes (1) Independence (INDEP) variable which takes 1 in the case that the board directors are independent and 0 otherwise. (2) The Board Size (BS) variable. The risk of noncompliance or non-credibility of banks caused by the lack of competence of the board members can encourage partners/customers to withdraw their funds, which in turn influences the bank's efficiency. (3) Ownership (OWN) variable includes the private ownership, the state ownership and the foreign ownership. Each of the ownership variables describes the contribution of the private sector, the government and the foreign actors to the bank's assets.

The main hypothesis to test are the following:

1) The independence of power in the hands of the Chairman, associated with the independence of the remaining board members, could affect positively the banking efficiency.

2) The bigger the number of the board members, the less is banking efficiency.

3) The high is the contribution of the private sector/the Sate/the foreign participation to the bank's assets, the high is banking efficiency

\section{Methodology and Data}

In order to estimate the efficiency scores from the Saudi Arabian banks, we feel in favor of the intermediation approach. Unlike some researches that use the efficiency input-oriented model, we examine the efficiency input-oriented model by applying the non-parametric DEA method on panel data. The bank is considered more efficient when less inputs are used to reach the same level of outputs. DEA is used to measure a Decision Making Unit (DMU) in a way that provides the maximum ratio of the proportion of outputs to the proportion of inputs. The DEA method requires bank inputs and outputs which choice is always an arbitrary issue. Using the DEA method allows us to calculate efficiency scores and to better explain inefficiency factors. The advantage of DEA is that it requires less data and can work with a small sample size. In addition, DEA gives an opportunity for outputs and inputs to be measured without pre-assigned weights being required. Finally, DEA is popular because it does not require the pre-specification of the production function. It is a linear-based technique and it 
can be used for small samples.

DEA can be described in the following equation:

$$
h_{s}=\frac{\sum_{i=1}^{m} u_{i s} y_{i s}}{\sum_{j=1}^{n} u_{j s} y_{j s}} \quad i=1, \ldots, m, j=1, \ldots, n
$$

Table 1. Variables definitions

\begin{tabular}{cc}
\hline$h_{s}$ & Efficiency for a Bank (s) \\
$I$ & Output \\
$J$ & Input \\
$M$ & The Total number of Outputs \\
$N$ & The Total number of Inputs \\
$\mu_{\mathrm{is}}$ & Amount of Output i produced by the bank (s) \\
$\gamma_{\mathrm{js}}$ & Amount of Input j used by the bank (s) \\
\hline
\end{tabular}

Source: The author.

Banker et al. (1984) introduced a model to assess the efficiency of a DMU, as indicated by variable returns to scale (VRS). The VRS allows us to measure the pure technical efficiency (PTE). The gap between technical efficiency (TE) and pure technical efficiency scores is called the scale efficiency (SE) of a particular DMU.

So that, it can be written as follows:

$\mathrm{TE}=\mathrm{PTE}+\mathrm{SE}$ implies that $\mathrm{SE}=\mathrm{TE}-\mathrm{PTE}$

The input-DEA model with regard to VRS can be written as follows:

$$
\begin{aligned}
& \text { Min } \varphi, \lambda, \varphi \\
& \text { Subject to }-\varphi y_{i},+\mathrm{Y} \lambda \geq 0 \\
& x_{i}-\mathrm{X} \lambda \geq 0 \\
& N 1^{\prime} \lambda=1 \\
& \text { And } \lambda \geq 0
\end{aligned}
$$

$\lambda$ is an $\mathrm{N} \times 1$ intensity vector of constants, $\Phi$ is a scalar $(1 \geq \varphi \geq \infty)$. N1 and $\mathrm{Nx} 1$ denote vector of ones: For $\mathrm{N}$

\begin{tabular}{|c|c|c|c|}
\hline Rank & Company & $\begin{array}{c}\text { Total assets } \\
\text { (SAR b, March 2017) } \\
\end{array}$ & $\begin{array}{c}\text { Total assets } \\
\text { (US\$b, March 2017) }\end{array}$ \\
\hline 1 & National Commercial Bank (NCB) & 448.717 & 121.470 \\
\hline 2 & Al Rajhi Bank & 337.230 & 91.290 \\
\hline 3 & Samba Financial Group & 231.935 & 62.780 \\
\hline 4 & Riyad Bank & 216.323 & 58.560 \\
\hline 5 & Banque Saudi Fransi & 204.358 & 55.320 \\
\hline 6 & Saudi British Bank (SABB) & 185.264 & 50.150 \\
\hline 7 & Arab National Bank & 168.427 & 45.590 \\
\hline 8 & Alinma Bank & 105.256 & 28.058 \\
\hline 9 & Alawwal Bank & 100.369 & 27.170 \\
\hline 10 & Saudi Investment Bank (SAIB) & 97.546 & 26.410 \\
\hline 11 & Islamic Development Bank (IDB) * & 96.110 & 25.624 \\
\hline 12 & Bank AlJazira & 65.114 & 17.630 \\
\hline
\end{tabular}
number of Banks, $\mathrm{X}_{\mathrm{i}}$ is $(m \times n)$ matrix and $\mathrm{Y}_{\mathrm{i}}$ is $(k \times \mathrm{n})$ matrix.

Our sample considers the 12 largest banks in Saudi Arabia according to their assets. Data are collected from the Bankscope database (2018) and annual reports of the following banks in table 2. Data are available from 2000 to 2017 period.

Table 2. List of the largest banks in Saudi Arabia

Source: The Saudi Arabian Monetary Authority (SAMA). 


\section{Main Results and Interpretations}

Table 3 shows the results of the annual efficiency scores of the Saudi Arabian banks from the annual efficiency scores. Technical efficiency results shows relatively high scores from 0.9014 at 2017 to 0.9481 at 2010 . The technical efficiency average score, the pure technical efficiency score and the scale efficiency score are respectively $0.9326,0.9539$ and 0.9499 .

Table 3. Annual efficiency scores

\begin{tabular}{cccc}
\hline Year & $($ TE $)$ & $($ PTE) & $($ SE) \\
\hline 2000 & 0.9458 & 0.9457 & 0.9587 \\
2001 & 0.9468 & 0.9489 & 0.9594 \\
2002 & 0.9312 & 0.9512 & 0.9614 \\
2003 & 0.9554 & 0.9578 & 09652 \\
2004 & 0.9355 & 0.9567 & 0.9671 \\
2005 & 0.9344 & 0.9577 & 0.9670 \\
2006 & 0.9403 & 0.9663 & 0.9615 \\
2007 & 0.9308 & 0.9643 & 0.9549 \\
2008 & 0.9217 & 0.9543 & 0.9458 \\
2009 & 0.9369 & 0.9563 & 0.9703 \\
2010 & 0.9481 & 0.9671 & 0.9701 \\
2011 & 0.9328 & 0.9540 & 0.9681 \\
2012 & 0.9348 & 0.9540 & 0.9371 \\
2013 & 0.9365 & 0.9582 & 0.9348 \\
2014 & 0.9255 & 0.9572 & 0.9245 \\
2015 & 0.9156 & 0.9585 & 0.9145 \\
2016 & 0.9148 & 0.9322 & 0.9125 \\
2017 & 0.9014 & 0.9314 & 0.9257 \\
\hline
\end{tabular}

Source: the author.

Table 4 presents the results of the impact of Corporate Governance variables on Technical Efficiency, Pure Technical Efficiency and Scale Efficiency of the Saudi Arabian Banks. The results illustrate the impact of the Independence variable (INDEP) on banking technical efficiency. The Independence (INDEP) variable has a positive and significant effect on efficiency in all regressions, indicating a positive relationship with the technical efficiency of the 12 banks in our sample. Separating the mission of the Chief executive and that of the board directors allows for quick decisions and adequate strategies. Outside directors from the board use strict rules and work to make the bank more efficient. As Mezzi (2018) argued, this result confirms that it is beneficial to promote more independence to the board of directors to improve banking efficiency. This finding reinforces the role of the board to improve banks' ability to better manage their costs for better efficiency. Indeed, Bulan et al. (2009) proposed that an independent board is more beneficial for banks. Kusuma and Ayumardani (2016) reported that outside directors minimize agency problems and improve banks' share value. In addition, competent and independent directors are able to better monitor and provide more valuable input to solve agency problems between owners and managers (Fama \& Jensen, 2009). According to the literature, independent directors allow for a better control of the management team and ensure that they pursue shareholders' interests, which may reduce agency conflicts. Therefore, we deduce that members' independence is an important feature that helps reduce distortion of banks, ensures more effective control of managers and control the bank's efficiency, According to Greuning and Bratanovic (2003), "A board of directors with a strong president who does not direct the activity of the bank will certainly have a healthy influence on the bank's policy than a board whose president is also the CEO".

Table 4 shows a negative and a significant effect of the Board Size on technical efficiency in all regressions. This is an expected result. A small number of directors may hinder adequate management of operations and then bank efficiency. Subsequently, we can conclude that an enlarged Board negatively affects technical efficiency. It is proved that an bank's board with reduced members is preferred to maintain bank efficiency and mitigates coordination problems, divergence of interests among members and supports decision making. This result is consistent with those of Lipton and Lorsh (1992) and Yermak (1996), who found that a reduced board size can enhance effectiveness and coordination between members and can also facilitate decision making. This implies that it can mitigate agency conflicts. 
Table 4 reports the results of the effect of the private ownership (OWEN-P) on banks' technical efficiency. (OWEN-P) has a positive and a significant effect on Islamic banks' technical efficiency. Islamic banks with higher degree of private shareholders are expected to be more efficient than other banks. In this case, the interest of managers is naturally aligned with those of the owners since the owners are also the managers. State ownership (OWEN-S) has a positive and a significant effect on the TE variable. High-level of State ownership in banks is often associated with a high frequency of price controls and strong regulation. The presence of Government seems necessary to help boosting bank efficiency. Government shareholders have the ability and the resources to discipline managers and to keep them away from opportunistic behaviors which enhances technical efficiency. Finally, foreign ownership (OWEN-F) has a positive and a significant impact on TE. The most advanced argument explaining better efficiency of foreign banks compared to local banks is that foreign banks are more efficient in managing risks and reducing costs (Ellouz \& Jawada, 2017). Besides, foreign ownership offers a superior access to technical, managerial and financial resources leading to a positive influence on bank's efficiency. Finally, for the other control variables, we found no statically significant relationship between these variables and Islamic banks' efficiency.

Table 4. The relationship between corporate governance variables and technical efficiency

\begin{tabular}{|c|c|c|c|c|c|c|c|c|}
\hline & $(1)$ & $(2)$ & (3) & (4) & (5) & (6) & (7) & (8) \\
\hline \multirow[t]{2}{*}{ INDEP } & $0.18 * *$ & & & & & $0.17 * * *$ & & $0.37 * * *$ \\
\hline & $(0.033)$ & & & & & $(0.033)$ & & $(0.035)$ \\
\hline \multirow[t]{2}{*}{ BS } & & $-0.015^{*}$ & & & & $-0.018^{*}$ & & $-0.020 * * *$ \\
\hline & & $(0.007)$ & & & & $(0.007)$ & & $(0.007)$ \\
\hline \multirow[t]{2}{*}{ OWN-P } & & & $0.019 *$ & & & & $0.129 * * *$ & $0.189 * * *$ \\
\hline & & & $(0.035)$ & & & & $(0.039)$ & $(0.044)$ \\
\hline \multirow[t]{2}{*}{ OWN-S } & & & & $0.186^{* * *}$ & & & $0.287 * * *$ & $0.357 * * *$ \\
\hline & & & & $(0.066)$ & & & $(0.067)$ & $(0.070)$ \\
\hline \multirow[t]{2}{*}{ OWN-F } & & & & & 0.004 & & $0.128 * * *$ & $0.135^{* * *}$ \\
\hline & & & & & $(0.035)$ & & $(0.040)$ & $(0.043)$ \\
\hline \multirow[t]{2}{*}{$\mathrm{TA}$} & $-0.008^{*}$ & $-0.09 * *$ & $-0.008 *$ & -0.006 & $-0.008 *$ & $-0.008^{*}$ & -0.006 & -0.006 \\
\hline & $(0.005)$ & $(0.005)$ & $(0.005)$ & $(0.005)$ & $(0.005)$ & $(0.005)$ & $(0.005)$ & $(0.005)$ \\
\hline \multirow[t]{2}{*}{ Deposit } & $-0.019^{*}$ & $-0.021 *$ & $-0.020^{*}$ & $-0.022^{*}$ & $-0.019^{*}$ & $-0.021^{*}$ & $-0.023^{*}$ & $-0.027 * *$ \\
\hline & $(0.012)$ & $(0.012)$ & $(0.012)$ & $(0.012)$ & $(0.012)$ & $(0.012)$ & $(0.012)$ & $(0.013)$ \\
\hline \multirow[t]{2}{*}{ Debt } & -0.003 & -0.002 & -0.004 & -0.001 & -0.005 & -0.005 & 0.003 & 0.009 \\
\hline & $(0.023)$ & $(0.023)$ & $(0.023)$ & $(0.021)$ & $(0.022)$ & $(0.023)$ & $(0.022)$ & $(0.022)$ \\
\hline \multirow[t]{2}{*}{ Credit } & 0.009 & 0.012 & 0.012 & 0.008 & 0.012 & 0.012 & 0.010 & 0.011 \\
\hline & $(0.008)$ & $(0.008)$ & $(0.008)$ & $(0.007)$ & $(0.008)$ & $(0.008)$ & $(0.008)$ & $(0.007)$ \\
\hline \multirow[t]{2}{*}{ GDP } & -0.125 & -0.179 & -0.147 & 0.019 & -0.176 & -0.196 & -0.125 & -0.109 \\
\hline & $(0.375)$ & $(0.375)$ & $(0.374)$ & $(0.372)$ & $(0.375)$ & $(0.374)$ & $(0.374)$ & $(0.371)$ \\
\hline \multirow[t]{2}{*}{ Constant } & $1.753 * * *$ & $1.833^{* * *}$ & $1.758 * * *$ & $1.690 * * *$ & $1.754 * * *$ & $1.833 * * *$ & $1.570 * * *$ & $1.713 * * *$ \\
\hline & $(0.089)$ & $(0.103)$ & $(0.087)$ & $(0.087)$ & $(0.089)$ & $(0.103)$ & $(0.092)$ & $(0.112)$ \\
\hline Observations & 216 & 216 & 216 & 216 & 216 & 216 & 216 & 216 \\
\hline Number of banks & 12 & 12 & 12 & 12 & 12 & 12 & 12 & 12 \\
\hline Pseudo R2 & 0.0009 & 0.0011 & 0.0009 & 0.0021 & 0.0009 & 0.0011 & 0.0026 & 0.0034 \\
\hline
\end{tabular}

Note. The first value shows the coefficient of each variable. The second value in parentheses, denotes Standard error variable.

$*, * *, * * *$ Denote degree of significance10,5 and 1 percent levels, respectively.

Table 5 reports a positive and significant relationship between INDEP and banks' Pure Technical efficiency. An independent board helps the bank to be managerially efficient to maximize their resources. In addition, Table 5 shows a negative and a significant impact of Board Size on PTE. Our result is in line with that of Johnson and Ellstrand (2007) who argued that better communication and coordination among members is efficiently possible through small board. Moreover, a decrease in the regular board size increases banks' pure technical inefficiency thanks to reducing costs (Ashfaq et al., 2017). Reporting on private ownership variables, Table 5 shows that the latter has a negative and a significant effect on PTE. According to Wei et al. (2011), abuse of rights exercised by private shareholders is potentially severe and affects the banks pure technical efficiency. State ownership has always the same positive and significant impact on Pure Technical Efficiency. According to OWEN-F variable, the assumption that foreign banks are associated with better efficiency than other banks has not been validated. 
This is because the impact of foreign ownership depends on both the understanding of the market and the country's regulation. We note that foreign ownership does not improve Pure Technical Efficiency.

Table 6 reports that INDEP has a negative and significant effect on scale efficiency (SE). Independent members reduce the scale efficiency of a bank. This finding confirms that the source of scale inefficiency of Saudi Arabian banks may be caused by the independence of the board members. Board size variable affects negatively and significantly the bank's Scale Efficiency. This impact may be due to coordination costs and free-riding problems as the source of scale inefficiency. Finally, all ownership variables affect positively and significantly scale efficiency. In other words, regarding foreign, state and private banks participation, the 12 banks of our sample seem to be operating at a relatively optimal scale of operations.

Table 5. The relationship between corporate governance variables and pure technical efficiency

\begin{tabular}{|c|c|c|c|c|c|c|c|c|}
\hline & $(1)$ & (2) & (3) & (4) & (5) & (6) & (7) & $(8)$ \\
\hline \multirow[t]{2}{*}{ INDEP } & $0.187 * * *$ & & & & & $0.325^{* * *} *$ & & $0.215^{* * *}$ \\
\hline & $(0.056)$ & & & & & $(0.057)$ & & $(0.059)$ \\
\hline \multirow[t]{2}{*}{ BS } & & $-0.02 * *$ & & & & $-0.031 * * *$ & & $-0.058 * * *$ \\
\hline & & $(0.009)$ & & & & (0.009) & & $(0.011)$ \\
\hline \multirow[t]{2}{*}{ OWN-P } & & & $-0.225 * * *$ & & & & $-0.715^{* * *}$ & $-0.632 * * *$ \\
\hline & & & $(0.050)$ & & & & $(0.160)$ & $(0.163)$ \\
\hline \multirow[t]{2}{*}{ OWN-S } & & & & $0.225 * * *$ & & & $0.179 *$ & $0.403^{*}$ \\
\hline & & & & $(0.096)$ & & & $(0.176)$ & $(0.183)$ \\
\hline \multirow[t]{2}{*}{ OWN-F } & & & & & $-0.059^{*}$ & & $-0.410 * * *$ & $-0.484 * * *$ \\
\hline & & & & & $(0.054)$ & & $(0.161)$ & $(0.164)$ \\
\hline \multirow[t]{2}{*}{$\mathrm{TA}$} & 0.001 & -0.001 & 0.002 & 0.002 & -0.002 & 0.001 & 0.001 & 0.002 \\
\hline & (0.006) & $(0.006)$ & $(0.007)$ & (0.006) & (0.006) & (0.006) & (0.006) & $(0.007)$ \\
\hline \multirow[t]{2}{*}{ Deposit } & $-0.058 * * *$ & $-0.060 * * *$ & $-0.058 * * *$ & $-0.062 * * *$ & $-0.057 * * *$ & $-0.063 * * *$ & $-0.058 * * *$ & $-0.068 * * *$ \\
\hline & $(0.018)$ & $(0.020)$ & (0.019) & $(0.021)$ & $(0.020)$ & $(0.018)$ & $(0.020)$ & $(0.020)$ \\
\hline \multirow[t]{2}{*}{ Debt } & 0.061 & 0.067 & 0.073 & 0.068 & 0.057 & 0.070 & 0.064 & 0.075 \\
\hline & $(0.063)$ & $(0.068)$ & $(0.070)$ & $(0.058)$ & $(0.058)$ & $(0.068)$ & $(0.049)$ & $(0.050)$ \\
\hline \multirow[t]{2}{*}{ Credit } & 0.021 & 0.022 & 0.022 & 0.016 & 0.019 & 0.023 & 0.012 & 0.013 \\
\hline & $(0.025)$ & $(0.027)$ & $(0.027)$ & $(0.022)$ & $(0.023)$ & $(0.027)$ & (0.019) & $(0.020)$ \\
\hline \multirow[t]{2}{*}{ GDP } & $-1.456^{* * *}$ & $-1.612 * * *$ & $-1.754 * * *$ & $-1.238 * *$ & $-1.241 * *$ & $-1.662 * * *$ & $-0.990 *$ & $-1.078 *$ \\
\hline & $(0.545)$ & $(0.553)$ & $(0.568)$ & $(0.548)$ & $(0.556)$ & $(0.554)$ & $(0.554)$ & $(0.553)$ \\
\hline \multirow[t]{2}{*}{ Constant } & $1.952 * * *$ & $2.200 * * *$ & $2.050 * * *$ & $1.921 * * *$ & $2.063 * * *$ & $2.205^{* * *}$ & $2.596^{* * *}$ & $2.804 * * *$ \\
\hline & $(0.123)$ & $(0.151)$ & $(0.123)$ & $(0.125)$ & $(0.125)$ & $(0.154)$ & $(0.187)$ & $(0.217)$ \\
\hline Observations & 216 & 216 & 216 & 216 & 216 & 216 & 216 & 216 \\
\hline Number of banks & 12 & 12 & 12 & 12 & 12 & 12 & 12 & 12 \\
\hline Pseudo R2 & 0.0107 & 0.0082 & 0.0095 & 0.0102 & 0.0078 & 0.0126 & 0.0174 & 0.0212 \\
\hline
\end{tabular}

Note. The first value shows the coefficient of each variable. The second value in parentheses, denotes Standard error variable.

$*, * *, * *$ Denote degree of significance 10,5 and 1 percent levels, respectively.

Table 6. The relationship between corporate governance variables and technical efficiency

\begin{tabular}{|c|c|c|c|c|c|c|c|c|}
\hline & $(1)$ & (2) & (3) & (4) & (5) & (6) & $(7)$ & $(8)$ \\
\hline \multirow[t]{2}{*}{ INDEP } & $-0.322 * * *$ & & & & & $-0.426 * * *$ & & $-0.126^{* *}$ \\
\hline & $(0.037)$ & & & & & $(0.037)$ & & $(0.039)$ \\
\hline \multirow[t]{2}{*}{ BS } & & $-0.045^{*}$ & & & & $-0.089 *$ & & $-0.015^{*}$ \\
\hline & & $(0.008)$ & & & & $(0.008)$ & & $(0.008)$ \\
\hline \multirow[t]{2}{*}{ OWN-P } & & & $0.078^{* *}$ & & & & $0.142 * * *$ & $0.384 * * *$ \\
\hline & & & $(0.043)$ & & & & $(0.0510)$ & $(0.054)$ \\
\hline \multirow[t]{2}{*}{ OWN-S } & & & & $0.047 * *$ & & & $0.997 * * *$ & $0.495 * * *$ \\
\hline & & & & $(0.076)$ & & & $(0.0812)$ & $(0.082)$ \\
\hline \multirow[t]{2}{*}{ OWN-F } & & & & & $-0.128^{*}$ & & $0.721 * * *$ & $0.292 * * *$ \\
\hline & & & & & $(0.044)$ & & $(0.0539)$ & $(0.058)$ \\
\hline \multirow[t]{2}{*}{ TA } & $-0.013 * *$ & $-0.012 * *$ & $-0.013^{* *}$ & $-0.011 * *$ & $-0.012 * *$ & $-0.013^{* *}$ & $-0.0102 *$ & $-0.012^{* *}$ \\
\hline & $(0.005)$ & $(0.005)$ & $(0.005)$ & $(0.005)$ & $(0.005)$ & $(0.005)$ & $(0.00531)$ & $(0.005)$ \\
\hline
\end{tabular}




\begin{tabular}{lcccccccc}
\hline Deposit & 0.015 & 0.014 & 0.016 & 0.014 & 0.015 & 0.015 & 0.0123 & 0.010 \\
& $(0.018)$ & $(0.020)$ & $(0.020)$ & $(0.020)$ & $(0.020)$ & $(0.018)$ & $(0.0197)$ & $(0.018)$ \\
Debt & $-0.066^{* *}$ & $-0.067^{* *}$ & $-0.074^{* *}$ & $-0.067^{* *}$ & $-0.069^{* *}$ & $-0.066^{* *}$ & $-0.0685^{* *}$ & $-0.062^{* *}$ \\
& $(0.027)$ & $(0.028)$ & $(0.030)$ & $(0.028)$ & $(0.028)$ & $(0.028)$ & $(0.0294)$ & $(0.029)$ \\
Credit & 0.010 & 0.011 & 0.010 & 0.009 & 0.010 & 0.010 & 0.0121 & 0.009 \\
& $(0.008)$ & $(0.008)$ & $(0.008)$ & $(0.008)$ & $(0.008)$ & $(0.008)$ & $(0.00828)$ & $(0.008)$ \\
GDP & 0.702 & 0.698 & $0.860^{*}$ & $0.798^{*}$ & $0.785^{*}$ & 0.700 & 0.698 & $0.770^{*}$ \\
& $(0.463)$ & $(0.463)$ & $(0.466)$ & $(0.454)$ & $(0.473)$ & $(0.466)$ & $(0.468)$ & $(0.466)$ \\
Constant & $2.105^{* * *}$ & $2.106^{* * *}$ & $2.036^{* * *}$ & $2.026^{* * *}$ & $2.062^{* * *}$ & $2.109 * * *$ & $1.792^{* * *}$ & $1.994^{* * *}$ \\
& $(0.096)$ & $(0.118)$ & $(0.093)$ & $(0.098)$ & $(0.094)$ & $(0.117)$ & $(0.105)$ & $(0.130)$ \\
Observations & 216 & 216 & 216 & 216 & 216 & 216 & 216 & 216 \\
Number of banks & 12 & 12 & 12 & 12 & 12 & 12 & 12 & 12 \\
Pseudo R2 & 0.0038 & 0.0021 & 0.0029 & 0.0022 & 0.0020 & 0.0038 & 0.0053 & 0.0069 \\
\hline
\end{tabular}

Note. The first value shows the coefficient of each variable. The second value in parentheses, denotes Standard error variable. $*, * *, * * *$ Denote degree of significance10,5 and 1 percent levels, respectively.

\section{Conclusion}

This article develops three hypotheses relation between the corporate governance variables, namely the independence of the board directors, the board size and the ownership structure, and the banking efficiency. We try to study in depth this relationship by providing some banking efficiency estimates related to the Technical Efficiency, the Pure Technical Efficiency and Scale Efficiency. So that our analysis include corporate governance proxies and three dependent efficiency variables (TE, PTE, SE).

The results of this study point to the significant role of The Independence (INDEP) variable supported by a positive and significant effect on efficiency in all regressions, indicating a positive relationship with the technical efficiency (TE), the pure technical efficiency (PTE). In the contrary, the independence of the board directors has a negative and significant effect on scale efficiency (SE).

According to Board Size (BS) variable, results related to this later reveal a negative and a significant effect on technical efficiency (TE), Pure Technical Efficiency (PTE) and Scale Efficiency (SE) in all regressions.

Finally, as for the ownership structure variables, results confirm that Private Ownership (OWEN-P) provides positive and significant effects on both the Technical and the Scale Efficiency. This effect seems to be turn to be negative and significant when it is correlated to the Pure Technical Efficiency. State Ownership (OWEN-S) impacts positively and significantly the Technical Efficiency, the Pure Technical Efficiency and Scale Efficiency separately. As for the Foreign Ownership (OWEN-F) variable, except for the Pure Technical Efficiency (PTE), we note a positive and significant effect on the Technical and Scale Efficiency.

The Saudi Arabian Monetary Authority (SAMA) should give some instructions to Saudi Arabian banks under supervision to better play their role in implementing good Corporate Governance mechanisms. Board Size and composition should be revised to let less members participate. Indeed, it seems that the bank Boards exceed their optimal size. In the other side, banks should encourage State ownership. Some revisions should be given to the private and foreign ownership in order to boost the banking efficiency and its components.

\section{References}

Adams, R. B., \& Mehran, H. (2012). Bank Board Structure and Performance. Evidence for Large Holding Companies, Journal of Financial Intermediation, 21(1), 243-267. https://doi.org/10.1016/j.jfi.2011.09.002.

Arouri, H., Hossain, M., \& Muttakin, M. B. (2014). Effects of Board and Ownership Structure on Corporate Performance: Evidence From GCC Countries. Journal of Accounting in Emerging Economies, 117-130. https://doi.org/10.1108/JAEE-02-2012-0007

Banker, R. D., Charnes, A., \& Cooper, W. W. (1984). Some Models for Estimating Technical and Scale Inefficiencies in Data Envelopment Analysis. Management Science, 30(9), 1078-1092. https://doi.org/10.1287/mnsc.30.9.1078

Belke, A., Ulrich H., \& Ralph, S. (2016). Regional Bank Efficiency and Its Effect on Regional Growth in 'Normal' and 'Bad' Times. Economic Modelling, 58(586), 413-26. https://doi.org/10.1016/j.econmod.2015.12.020

Cevik, N., K., Sel, D., \& Ali, M. K. (2016). Real and Financial Sector Studies in Central and Eastern Europe: A 
Review. Czech Journal of Economics and Finance, 66(1), 2-31.

Cvilikas, A., \& Edita, J. (2016). Assessment of Risk Management Economic Efficiency Applying Economic Logistic Theory. Transformations in Business \& Economics, 15(3), 207-19.

Diallo, B. (2018). Bank Efficiency and Industry Growth during Financial Crises, Economic Modelling, 68(Issue.C), p11-22. https://doi.org/10.1016/j.econmod.2017.03.011

Ellouz, S., \& Jawada, M. (2017). The Determinants Of Technical Efficiency: Case Of Islamic Banks. Australian Journal of Basic and Applied Sciences, 11(6), 12-24.

Fama, E., F., \& Jensen, M. C. (1985). Separation of Ownership and Control. Journal of Law and Economics, 26(1), 301-25. https://doi.org/10.1086/467037

Greuning, H. V., \& Bratanovic, S. B. (2003). Analyzing and Managing Banking Risk: A framework for assessing corporate governance and Financial Risk. The World Bank, Washington D.C.

Ibrahim, E. A. (2017). The Impact of Corporate Governance on Islamic Banking Performance: The Case of UAE Islamic Banks. Journal of Banking and Finance, (9), 1-10.

Kusuma, H., \& Ayumardani, A. (2016). The Corporate Governance Efficiency and Islamic Banks Performance an Indonesian Evidence. Polish Journal of Management Studies, 13(1), 111-120. https://doi.org/10.17512/pjms.2016.13.1.11

Lipton, M., \& Lorsh, J. W. (1992). A Modest Proposal for Improved Corporate Governance. Business Lawyer, 48(1), 59-77.

Mezzi, N. (2018). Efficiency of Islamic banks and role of governance: Empirical evidence. Managerial Finance, 44(5), 590-603. https://doi.org/10.1108/MF-05-2017-0171

Rekha, P., \& Husam-Aldin, N. Al-Malkawi. (2018). On the relationship between corporate governance and firm performance: Evidence from GCC countries. Research in International Business and Finance, 44(issue C), 394-410. https://doi.org/10.1016/j.ribaf.2017.07.110

Titova, Y. (2016). Are Board Characteristics Relevant for Banking Efficiency? Evidence from the US, Corporate Governance. The International Journal of Business in Society, 16(4), 655-679. https://doi.org/10.1108/CG-09-2015-0124

Upadhyay, A., \& Sriram, R. (2011). Board size, Corporate Information Environment and Cost of Capital,

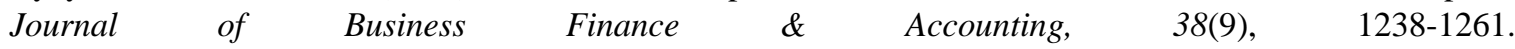
https://doi.org/10.1111/j.1468-5957.2011.02260.x

Yamori, N., Kozo, H., \& Kei, T. (2017). Corporate governance structure and efficiencies of cooperative banks. International Journal of Finance \& Economics, 22(4), 368-378. https://doi.org/10.1002/ijfe.1593

Yermack, D. (1996). Higher Market Valuation of Companies with a Small Board of Directors. Journal of Financial Economics, 40(2), 185-221. https://doi.org/10.1016/0304-405X(95)00844-5

Yizhe, D., Claudia, G., \& Jing-Ming, K. (2016). Governance, efficiency and Risk Taking in Chinese Banking. The British Accounting Review, 1(19), 331-360.

Zhang, L., Sheng, Z., \& Na, T. (2016). Financial System Risk Tolerance Capacity and Economic Growth: Evidence from a Cross-Country Analysis. Global Economic Review, 45(2), 97-115. https://doi.org/10.1080/1226508X.2015.1124343

\section{Copyrights}

Copyright for this article is retained by the author(s), with first publication rights granted to the journal.

This is an open-access article distributed under the terms and conditions of the Creative Commons Attribution license (http://creativecommons.org/licenses/by/4.0/). 